\title{
Turkish Nationalism and the Incorporation of Migrants and Minorities into the Turkish State: a Study in the Civic and Ethnic Contours of Turkish Nationalism

\begin{abstract}
This article uses the integration of immigrants and minorities into Turkey as a lever to investigate the boundaries of Turkish nationalism. Turkish nationalism is often treated as an ethnic nationalism, and that's indeed how it was thought of by many of its Ottoman founders. However, the legal system is constructed in a largely civic way, such that ethnic heritage-in theory-does not matter for citizenship. Immigrants and domestic minorities provide a useful lens to look at who is included within the category of "Turk". This article uses the integration of immigrants and minorities into Turkey as a lever to investigate the boundaries of Turkish nationalism. Turkish nationalism is often treated as an ethnic nationalism, and that's indeed how it was thought of by many of its Ottoman founders. However, the legal system is constructed in a largely civic way, such that ethnic heritage-in theory-does not matter for citizenship. Immigrants and domestic minorities provide a useful lens to look at who is included within the category of "Turk".
\end{abstract}

Keywords: Turkish nationalism; migration; minorities; state; civic; ethnic.

\section{Introduction}

In particular, this article argues that there is an ethno-religious limit to incorporation, such that only Muslims can easily be imagined as part of the Turkish political community. However, among Muslims, traditionally ethnic descent was not required for Turkish belonging, and voluntaristic adaption of perceived Turkish customs (above all: language, at least in addition to any minority language) was seen as key to belonging. In that sense, Turkish nationalism combines both ethnic and civic characteristics - as do many European nationalisms, from the Early Modern period onward. Indeed, nationalism cannot only be about the inclusion of one group; the boundary making processes must involve the exclusion of others, often very specific groups. For the present volume, the most relevant fact is that Muslim migrants from outside modern Turkey-even ones with no Turkic heritage-were includable in the national imagination even as non-Muslim sons of the soil were implicitly excluded from national imaginings.

\footnotetext{
\pm Jared Conrad-Bradshaw, Department of Sociology, University of Columbia, New York, United States. E-mail: Jcb2212@columbia.edu/jaredconradbradshaw@gmail.com.
} 
But in order to understand the incorporation of migrants into the Turkish political imagination, it is first necessary to understand the contours of nationalism more broadly.

\section{Civic, Ethnic, and Beyond: the Theoretical Background}

Most scholars of nationalism have accepted Anderson's definition of the nation as an "an imagined political community-and imagined as both inherently limited and sovereign." (Anderson 2006:5). Likewise, most scholars are willing to use some version of Gellner's definition of nationalism, agreeing that national is roughly "a principle which holds that the political and national unit should be congruent" (Gellner 2008:1). While later scholars have tweaked Gellner's definition (e.g. Hechter 2000:7-15; Hobsbawm 2012:9-13), the core idea of it - that nationalism involves collective action to bring politics and culture into union-has proven resilient. $^{1}$

However, within these widely accepted definitions of nation and nationalism, there is little consensus about how to classify different forms of nationalism. John Breuilly (1994) sets up a $3 \times 2$ table for six types of nationalism (separation, reform, unification $\mathrm{x}$ opposed to non-nation states, opposed to nation-states). Michael Hechter (2000) proposes four main types of nationalism (state-building, peripheral, irredentist, and unification nationalism, all of which he separates from "patriotism" which argues is specifically not nationalism), but notes that his typology "is not exhaustive" (Hechter 2000:17). There are more extreme examples. For example, as Rogers Brubaker (2006:113) notes:

In his early book Theories of Nationalism (Smith 1971:211-29), for example, Anthony Smith classified national movements by the "formal" criteria of "intensity" and "achievement" and by the "substantive" criteria of "independence" and "distinctive-ness." The former yielded six types, the latter 12; cross-classifying them, with some simplification, yielded no fewer than 39 types for which Smith found corresponding historical or contemporary instances.

Though the works that propose these classificatory are widely cited, none of these typologies have been widely adopted. While the above cited

\footnotetext{
${ }^{1}$ This idea arguably predates Gellner and, depending on how much one squints, can be traced all the way back to Hans Kohn (2005) in the 1940's, which was in many ways the starting place for the perennialist/modernist debates of nationalism. Because of this, the space between these two widely accepted definitions, that a nation might not imply nationalism directly and that while the latter is modern the former may be in certain senses quite ancient, is the space within which Anthony Smith's ethnosymbolism resides.
} 
works (and several others like them) are all seen as broadly useful discussions of variations within nationalism, their specific classification schemes are far less popular and seem rarely used except, perhaps, by the authors' own graduate students.

Indeed, there is to my knowledge only one typology of nationalism that has received widespread adoption: the differentiation between civicterritorial defined nations and cultural-ethnic defined nations. This definition is often credited to Anthony D. Smith, who developed the distinction under these specific names in a series of works in the 1980's (Smith 1989, 1991), just as this new wave of nationalism research led by the likes of Hobsbawm, Anderson, and Gellner was taking hold. However, Rogers Brubaker (2006:133) points out that this sort of distinction has a much older heritage. Brubaker has argues that not only does this distinction largely recreate Hans Kohn's 1940's distinction between "Western" and "Eastern" forms of nationalism, ${ }^{2}$ but it goes back even further, to Friedrich Meinecke's 1907 distinction between Staatsnation and Kulturnation, that is, a nation defined by the state and a nation defined by culture.

Brubaker goes on to criticize the distinction at length (2006:132-146), arguing that it should be replaced by another distinction, one which I will discuss in more detail below. Brubaker's criticism is particularly important because Brubaker himself did much to popularize the notion in the early 1990's with his masterwork Citizenship and Nationhood in France and Germany (Brubaker 1992). Though Brubaker somewhat curiously never cites Smith on the topic in Citizenship and Nationhood in France and Germany, France and Germany in his work often clearly stand in for two ideal types: French-like systems where citizenship and nationhood are applied to all those within state boundaries who adopt a certain statedefined way of life, and the German-like systems where citizenship and nationhood are applied to all of those who belong to a certain, in theory descent-based, ethnic group. While the Provençals, Basques, Bretons, and other indigenous minorities could be assimilated into "Frenchness", as Eugene Weber famously described two decades before Brubaker (Weber 1976), German minorities like the Poles, the Sorbians, and most famously the Jews could never fully be included in the German nation or state. However, ethnic Germans beyond the borders of any and every German state, real and proposed, ${ }^{3}$ were consistently included in this imagining of

\footnotetext{
${ }^{2}$ Writing in the 1940's, Kohn was discussing Western and Eastern European forms of nationalism. Germany, for instance, is "Eastern".

${ }^{3}$ The main debates in German nationalism of the $19^{\text {th }}$ century was between a Grossdeutschland which included Austria and Kleindeutschland which did not. While both these pre-World War I conceptions of Germany did include populations like the East Prussian German populations (the largest
} 
the nation. That is, classically, we end up talking about the civic French who imagined their nation including assimilated minorities within the French state and the ethnic Germans who imagined themselves united with coethnics abroad-indeed, civic and ethnic, the classical terms popularized by Smith, are even the exact terms Brubaker himself uses to discuss the differences in French and German nationalism in his 1992 book.

However, when returning to the subject in a book chapter in 2006, Brubaker strongly criticizes this ethnic -civic distinction, as mentioned above. He points out that the definitions of ethnic and civic are unstable, particularly around the definition of which side controls a "culture". Some authors have defined civic nationalism in such a way that almost everything is civic: Catalan, Scottish, and Quebecoise separatist nationalisms, for instance, have all made specifically civic claims, that they stand for all the people of those regions culturally, regardless of peculiar ethnic heritage. Other authors have done much the opposite. Anthony D. Smith himself, Brubaker argues, in some of his works looking at the long historical arc of national identities before the advent of nationalism, posits that ethnicity is nothing more than culture, thus leaving little room for civic nationalism. Not only do we see analytical ambiguities, Brubaker argues, but we see large normative ambiguities. While many scholars tend to assume that civic nationalism is voluntaristic and ethnic nationalism is ascriptive, we often see these play out in the opposite fashion. For instance, the rash of people Finns and Hungarians voluntarily choosing to change their names to better signal their ethnic belonging during respective national awakenings on the one hand, and the simple fact that, even in the most "civic" societies like immigrant-based settler colonial countries, citizenship and national belonging continues to be something from birth, on the other.

Brubaker proposes an alternative to this. He argues that, instead of ethnic and civic, we should think of "state-framed nationalism" and "counter-state nationalism". Catalan, Scottish, and Quebecoise nationalism - or to choose a more local example, Kurdish nationalismthus become counter-state nationalisms, bracketing entirely the question of who precisely they include. Spanish, British, and Canadian nationalismor again to choose another local model, Turkish nationalism-become state-framed nationalisms. Here, Brubaker misses the forest for the trees. Remember our earlier distinction between the nation as a political imagining à la Anderson and nationalism as a social movement à la Gellner.

East Prussian city, Königsberg, now forms the core of the Russian exclave of Kaliningrad), they generally did not include other German populations further afield like the Baltic Germans (who taken out of the region in World War II and its aftermath) or the Volga Germans (who have largely left Russia since the Fall of the Soviet Union). 
The original question was less about the strategy of the nationalism and more about the question of who is included in the nation. The question that Brubaker ties to avoid-precisely who is included in the nation in these various nationalisms-is precisely the one that this civic and ethnic distinction is useful in answering. The relationship these nationalisms-as ideological -isms-have with already-existing states is another question entirely.

Remember Anderson's widely adopted definition of the nation: the nation is "an imagined political community". Who is imagined inside and who is imagined outside? One way to understand this avoidance of this question is that, in the years since the publication of Citizenship and Nationhood in France and Germany, Brubaker has often worked on the difficulties of understanding identity analytically. In articles like "Beyond 'Identity'" (Brubaker and Cooper 2000) and "Ethnicity without Groups" (Brubaker 2002), Brubaker has sought to show that identities are typically layered and multiple, and frequently in conflict. Though this particular expression comes from an anonymous Arab-Israeli public figure speaking Israeli Or Commission investigating the causes of the Second Intifada, the feeling that "my state is at war with nation" is the tension that many in the world feel.

\section{Incorporation into the Turkish State, Incorporation into the Turkish Nation}

In the local Turkish context, we can see how these multiple imagining play out. We can easily understand that the major political parties tend to understand belonging in the Turkish nation rather differently: the CHP may emphasize Anatolian Turkish heritage possibly to the exclusion of all other Anatolian identities; the AKP has at times emphasized the shared heritage of all Anatolian Muslims (for instance, this was much of the rhetoric of the "Kurdish opening"); and the MHP may emphasize that the Turkish nation is spread in a long arch beyond the borders of the Turkish state, all the way into Central Asia and even China. And, of course, even within all those parties, remains real heterogeneity such that we can find many MHP members who emphasize the inclusive, civic aspects of the Turkish state and AKP members who emphasizes the unity of a single Turkic people across states.

However, here, for the remainder of the paper, I want to focus on Turkish nationalism as a matter of state policy, and how it has blended both civic and ethnic characteristics. Methodologically, there obviously are strong limitations to studying any sort of cultural movement simply through state policy, but it is here at least an early step. The mix of civic and ethnic 
features in Turkish nationalist policy is in part because "nations" (milletler) of the Ottoman Empire were made out of different sorts of categories from pre-modern Eastern and Western European nations. Nations in the multinational Ottoman Empire were not defined by language (as was typical in Eastern Europe) or the boundaries of the state (as was common in Western Europe), but by religion above all. This made subsequent Ottoman and post-Ottoman nationalist movements mobilizing largely, but never exclusively, on linguistic lines different from their European counterparts even as they sought to follow European models.

Scholars have, of course, pointed out the importance of religion for boundary making among pre-modern European nations. John Armstrong's Nations before Nationalism (1982) argues convincingly that before linguistic-based nationalism, European nations were much focusing on belonging in a "Christian" nations. Religions were, he argues, "nations before nationalism". This was certainly the case in the Ottoman Empire, as before Greek, Bulgarian, Armenian, and later, Turkish, Arab, and Kurdish nationalist movements took hold, "national" identity in the Ottoman Empire was largely religiously defined in the millet system. While the details vary over time (Barkey 2005, 2008; Braude 1982), for much of the Empire, the effective millets were the Muslims, Apostolic Eastern Orthodox, the Oriental Orthodox Armenian Church, and the Jews. As the millet system became more formalized, and more categories were added, they were always new types of Christians, rather than nations based on territory or linguistic groups. By the end of the $19^{\text {th }}$ century, for instance, there were formally three separate Armenian-speaking millets divided on Gregorian, Protestant, and Catholic sectarian lines, but an the Rum Greek millet actually included both Greek- and Arabic-speaking "Greek Christians".

That alone, however, does not give particularly strong insight into how such religious legacies play into contemporary post-Ottoman nationalisms, as many of these nationalisms did become linguistically- (as in the Greeks, the Armenians, the Bulgarians, Pan-Arabism) or territorially- (as in the local Arab nationalisms) rather than religiously-based as they had been in the Ottoman system. Anthony Marx's Faith in Nation: the Exclusionary Origins of Nationalism (Marx 2003) is more empirical take along the lines of Armstrong's often theoretical work, arguing that the roots of the supposedly inclusive "civic" nationalism of France, England, and Spain were all defined by clear and early episodes of religious exclusion. The Spanish State may long have tried, mostly unsuccessfully, to have a single national identity that is open to both Catalonians and the Castilians, but the origin of its national identity comes from expelling Jews and Muslims-and not just expelling them, either, but carrying on a long inquisition to ensure they 
were truly gone. France may more successfully include the Basques, the Occitans, and the Bretons, but that $19^{\text {th }}$ century unity is in many ways made possibly by $17^{\text {th }}$ century brutal expulsion of Protestant Huguenots. Conversely, much of $19^{\text {th }}$ British unity among the English, Scottish, and Welsh comes from political (rather than physical) exclusion of on the one hand Catholics and "non-conforming sects" on the other. While France and Britain and, to a less degree, Spain managed great culturally unity in the Modern Era, from the French Revolution onward, this modern "civic" and "inclusionary" unity was largely set up by religious exclusion in the Early Modern Era. This Early Modern religious exclusion becomes the glue that held these Modern nations together.

\section{Religious Boundaries in a Linguistic World}

Now, let us turn more broadly to the topic of this conference, which is international migration. We all know how Turkish nationalism was religious exclusionary, as in the cases discussed by Marx above, particularly in terms of the Anatolian Christian populations which, for the part, fled or were otherwise expelled, killed, or exchanged from Anatolia and Eastern Thrace in the decade of fighting between the start of the Balkan Wars in 1912 and the establishment of Turkish independence in 1923. Similar things happened in the Balkans and the Caucasus, but in the other direction, with much of the Muslim population facing the same outcomes. One interesting thing about the conclusions to this mutual ethnic cleansing of the Balkans and the Caucasus, is that even as late as the 1920's, when language-based ethnic affiliation had been the source of national mobilization for decades, these ethnic boundaries were still enforced by the state on religiously, rather than linguistically, defined lines. The famous population exchange between Greece and Turkey, where 1.5 million "Greeks" were transferred to Greece and half a million "Turks" were transferred to the new nation of Turkey was not really about Greeks or Turks at all: the terms of the treaty were all religiously defined (Clark 2009). Christians went one way, Muslims the other. Greek-speaking Muslims from Thrace and the Of district of Trabzon, for example, ended up in Turkey (Meeker 2002). Turkish-speaking Orthodox Christians from Cappadocia ended up in Greece. Kurdishspeaking Syriacs and Armenians largely, but not entirely, met the fate of their co-religionists, not those they shared a language with. The Turkish Republic was secular, but its imagination of the Turkish nation was a (secular) Muslim one. ${ }^{4}$

\footnotetext{
${ }^{4}$ This is far from unique: secular European countries have long had special relationships with their dominant religious group. Sweden, for instance, was both long secular and had an official church, only
} 
Much is usually made of these mainly Christian emigrants, emphasizing the exclusionary nature of Turkish nationalism, but too little is made of these immigrants, showing the inclusionary nature of Turkish nationalism, particularly during the early Republican period. This, I am sure, is not usually the terms many of the good liberals in this audience are used to thinking of Turkish nationalism. In fact, we generally think of Turkey as a country that sends out emigrants - not just Christians in World War I, but ethnic Turks and Kurds to Germany, the Netherlands, and other European destinations-rather than a country that takes in immigrants.

We should, however, spend a little more time thinking of Turkey as it doesn't want to: as a nation full of assimilated immigrants. The historian Erik Jan Zürcher has made this point quantitatively in terms of the leader of Turkish nationalism (Zürcher 2003, 2005). He first made the point that the Young Turk leadership was largely "children of the borderlands", that they, for the most part, came not from the Turkish majority regions of Anatolia, but from marginally Turkish, ethnically mixed regions. He goes through all the important groups of Young Turks individually, but for now it may be enough to remind you that, of the Triumvirate that ruled during the preRepublican Young Turk period, Talat Pasha was from Bulgaria, Enver Pasha was from mixed ethnically Constantinople to the a Gagauz Turk father and Albania peasant mother, and Cemal Pasha was born on the now-Greek island of Lesbos. The leadership broadly, though by self-identity simply "Turkish", came from similar diverse backgrounds. Others have emphasized that Turkism was largely, in its earliest stage, an international endeavor, involving not just Turks in the Ottoman Empire, and Turks and even more broadly Muslims in both the Ottoman and Russian Empires (Meyer 2014).

In a follow up article to his "Children of the Borderlands" thesis (Zürcher 2005), Zürcher argues that, after the failure of the Young Turks, it was a sociologically almost identical group of European Muslims who "adopted" Anatolia and created modern Turkey. Zürcher again goes into the quantitative make up of the various leading lights of Early Republic, where many of the leaders were Muslims from peripheral regions, but I will just mention here my favorite example that I think shows the range of this Turkish territorial civic idea. Nazim Hikmet is perhaps Turkey's most famous poet. A well-known Marxist poet, he was generally treated by the Kemalist regime as an opponent, and he ended up frequently in jail. But yet he had

disestablishing the Lutheran Church in 2000. Secular The United Kingdom still has an established Church. France and Germany, while not having established Churches, still have special relationships with the dominant religious organizations there (in France, the Catholic Church; in Germany, both the Lutheran and Catholic Churches). Secularity in such contexts often practically means benefits for moderate forms of the dominant religion (Sullivan 2005). 
an almost identical imagination of the Turkish nation as that of his supposed ideological opponents. One of his most famous poems, "Vasiyet", that is his "Will and Testimony", begins:

Yoldaşlar, nasip olmazsa görmek o günü,

ölürsem kurtuluştan önce yani,

alıp götürün

Anadolu'da bir köy mezarlığına gömün beni.

Or in English, "Comrades, if I don't live to see the day/-I mean, if I die before freedom comes-/take me away/and bury me in a village cemetery in Anatolia." This personal, nostalgic association with Anatolian would be impossible without a very particular, but common, imagining of the Turkish nation: Hikmet was born in Salonica, in modern day Greece, and did not set foot in Anatolia until he was an adult. His connection to Anatolian villages comes through nationalist imagining, not personal experience. Civic nationalism is often called territorial for a reason, as it inspires not only an imagining of a relationship between people and a state, but between people and a specific piece of land. In the 1920's and 30's in particular, the mainstream nationalist movements emphasized a close association with the land (Gürpinar 2012). This association in Turkey will be of little surprise to Turkish readers, as they live this association often. As one small example, masthead of the Hurriyet newspaper has long carried the phrase, Türkiye Türklerindir, "Turkey belongs to the Turks": territorially based nationalism as banal as a newspaper slogan.

Though most of the Turkish nationalist leaders mentioned in Zürcher's pieces had at least one parent who identified as ethnically Turkish, this is not always the case. For instance, the most important ideologue of Turkish nationalism, Ziya Gökalp, is likely ultimately of Kurdish descent and, in typical civic nationalism fashion, voluntaristic adopted Turkish identity, and Turkish nationalism, as his own. Many of the immigrants to Anatolia were more like Gökalp than Atatürk or Hikmet, in that they had thin if any claims to Turkish ethnic descent but fully embraced a Turkish identity. The American historian Justin McCarthy (1995) examines ethnic cleansing of Ottoman Muslims in the century between Greek independence and Turkish independence. He estimates that five and a half million Ottoman Muslims were killed and that five million were forced from their homes, most ending up in Anatolia. These were of course not just ethnic Turks, but a variety of Muslim ethnic groups from the Balkans and the Caucasus: Albanians, Bosnians, Circassians (Çerkez), Pomaks, Azeris, and so forth. Ottoman Anatolia and later the modern Republic of Turkey became a refuge not just 
for Turks, but essentially all threatened Balkan and Caucasian Muslims. McCarthy (1995) estimates that $1 / 5$ of all of Turkey's population is descended from these migrants, making it a nation immigrants in a way that few today recognize or discuss. Why? In large part because these various groups more or less seamlessly were assimilated into "Turkishness".

We have relatively little information about these people's assimilation progress because of how quickly, like Nazim Hikmet, most assimilated into the dominant imagination of Turkey's political community. Men with little connection to Anatolia became passionate Anatolians.. I have had multiple friends who only as adults realized that they were descended from Albanians and Circassians, and in fact, that their fathers (in Turkey, ethnic and similar forms of self-identity are generally transmitted through the male line) actually spoke Albanian and Circassian fluently. While in the wake of James C. Scott, much of the literature on identity is about "resistance" to hegemonic identities and power structures (Scott 1985), there is very little record of non-Kurdish Muslim resistance to this homogenous Turkish imagining. One hears about Çerkez Ethem, "Ethem the Circassian", as one of the few non-Kurds who openly resisted the state's insistence on this uniform Turkish identity. Even in this case, it should be emphasized, that even other members of his family assimilated: one of his brothers ended up as a member of parliament from Manisa, and another was a senior member of the Turkish army. While Ethem resisted Turkish identity, even is own brothers did not. During an aborted research project among ethnic Circassians in the Kayseri region, where there continue to be dozens of Circassian-speaking villages, I found that most feel simultaneously Circassian and Turkish.

Most of these groups do not show up in the historiography of Turkey. These migrants, many of whom ended up in areas in Western Turkey that had once held large Christian populations, do turn up occasionally in ethnographies conducted by Western anthropologists. One interesting is how little their foreignness is emphasized. The political scientist Arnold Leder (1976) studied the town of Saruhanlı, in Manisa, in the 1970's. The town was home to two waves of Muslim migrants from Bulgaria, one during the Republican period and one pre-Republican. Leder found that these two groups of migrant did act as political blocs, but interestingly each bloc ended up on opposite sides of the political divides of the town. Their shared social ties of migrations were politically relevant, but their shared experience of migration to Turkey or even being "Bulgarian Turks" was not, that is, it was the actual social ties that mattered, not the fact that both groups ultimately were outsiders in from the same place. They both quickly were assimilated into the political and economic system of the town. They 
were known as göçmen, "migrants", but only in local terms: they were unambiguously included in the national imagination, while only peripherally included initially in the local one.

Paul Magnarella studied a rather different community (Magnarella 1979), a group of Georgian Muslims who settled in the Bursa province. As an example of how rich this area was with migrants, these Georgians originally competed with a group of Circassians to settle in this particular spot, ultimately winning and sending the Circassians to settle a spot a little further down the road. When Magnarella studied this group in the 1970's, it was a bilingual community, but one where Georgian was still very much alive among the villagers. Their foreignness is actually rather little commented on because they were so-assimilated into the Turkish sphere. They were allowed to carry two identities simultaneously without it calling into question their belonging in the Turkish national imagination. They had adopted certain Turkish customs, like accepting cousin marriage which had previously been totally taboo, but remained linguistically distinct. They had a layered identity impossible in ethnic states, but common in civic ones: they were both Turkish and Georgian. Though, as we will see things have changed, this continues to the present day. As with the Circassian I met in Kayseri, it was possible to be "both/and". As a third example, the recent Turkish Nobel prize winner, Aziz Sancar, is from the town of Savur in the province of Mardin, is both proudly Turkish and ethnically Arab. While, like the case of Sancar, they are not actually immigrants, the anthropologist Michael Meeker has conducted a long study of the traditional Greekspeaking town of Of in Trabzon, where residents start as being more Muslim than the Muslims and later become more patriotically Turkish than even surrounding groups (Meeker 2002).

Some of these, like those in Of, end up entirely assimilated, but in other groups the assimilation was more tentative. In the Circassian population I worked wit in Kayseri, the identity of "Turkish" was sometimes "us" and sometimes "them", as it seems like it was for Magnarella's Georgians. While it seems their Turkish neighbors are generally more eager to class them as included in the category of "Turks", as Magnarella's ethnography shows, in certain contexts they are still imagined outside of the category. In terms of participation in the nation as it is relevant to the state, however, they are full included, and not merely ambiguous edge cases case by accidents of citizenship as the non-Muslim minorities of Istanbul and Izmir are often seen (see, for instance, Brink-Danan 2009, 2010, 2012; Ekmekçioğlu 2016).

Because of the Republic's more inclusive policies, minorities in some other places were eager to join it. And this is not just migrants from Christian-majority states. Though not quite migrants, when the ethnically 
mixed Hatay district was deciding whether to remain part of Syria or become part of Turkey, many Arab-speaking Alevis chose to join the more civic Turkey rather than Syria, where they were worried that as religious minorities they would be treated as more of second class citizens in a more emphatically Sunni Syria (Shields 2011). They did not come to Turkey, but they brought to Turkey to where they were. While unfortunately it is hard to track the current ethnic identification of their descendants because Turkey has not asked ethnic identification questions on its census for decades, anecdotal evidence suggests that many have chosen to assimilate into Turkishness. One close friend of mine, for instance, has three grandparents with Arabic as a mother tongue and one grandparents with Kurdish as a mother tongue. Her father identifies ethnically as Kurdish, but both she and her brother ethnically identify simply as Turkish without adjective. Their ethnic origin, the reality of their descent, was no obstacle to assimilation so long as they were willing to reimagine themselves as belonging to the Turkish nation, as one would expect from civic nationalism.

No matter how Turkey has treated its migrants-cum-Turks, one persistent challenge to arguing that Turkey has traditionally had a civic nationalism is the issue of Kurds. Scholars like Uğur Ümit Üngör have argued, correctly, that the Young Turk and Kemalist governments engaged in "social engineering" of Eastern Anatolia (Üngör 2008, 2011). Üngör argues that the Young Turk murder and expulsion of the Armenians was of a piece with the later Kemalist policies towards the Kurds in the same region. Both, he argues, had the goal of making Eastern Anatolia a Turkish space. While this is true, that the Turkish nationalists particularly, after 1923 set Turkey and the Turk's territorial and cultural Western boundary, were very concerned about Eastern Anatolia. However, the different ways the nationalists dealt with the two populations says a great deal: the Kurds could, and ideally should, be assimilated in ways that the Armenians couldn't be. Islam was a sort of religious basis for the possibility of full civic inclusion in this Kemalist imagining of Turkishness.

It is clear that, like the Muslim migrants from the Balkans and the Caucasus, the Turkish state hoped to assimilate the Kurds of the Southeast. Üngör, for instance, documents policy of rebellious Kurdish elites being brought to Western with the hope of assimilation. This was, perhaps, more active than modern French and Spanish assimilationist policies, but it comes from the same sort of desire to create a culturally homogenous nation out of a culturally heterogeneous population that is common for civic nationalism. The layeredness of Turkish and non-Turkish identity seemingly was largely accepted by most members of Turkey's Georgian Muslim, Circassian, and Laz minorities, and to some degree accepted by the 
Arab minority, but mostly rejected by Kurdish citizens of Turkey and largely not offered to the non-Muslim minorities.

This layered identity, perhaps, is no longer available as it once was in the early Republic Period, as Turkish nationalism has changed. It is worth noting that later scholars have even argued this policy has changed: many Turkish nationalists have increasingly adopted an ethnic, rather than civic, frame towards the Kurdish population, particularly in response to the violence in the Southeast in the 1980's and the subsequent mass migration of Kurds from the Southeast into Western cities (Al 2015; Ergin 2014; Saraçoğlu 2010; Yeğen 1999, 2009). Mesut Yeğen (2009) puts this argument particularly crisply when he argues mainstream Turkish nationalist discourse has moved from seeing Kurds as "Prospective Turks" toward seeing them as "Pseudo-Citizens". This process, he argues, is still on going and is actively being negotiated. It is worth noting that many have tried create a civic nationalism where the role of Kurds in modern Turkey is neither as prospective Turks nor as "pseudo-citizens". This was, of course, the ultimate goal of the AKP's "Kurdish Opening", among many other initiatives, generally either from the liberal left or the religious right, that has sought to find a form of ethnic multi-culturalism under the umbrella of some greater unity. Time will tell how the Syrian refugees currently living in Turkey-some of whom will inevitably never return to Syria-will or won't assimilate into the imagined Turkish political community: will they end up as a distinct minority like the Kurds or will they have a layered identity like the Circassians?

\section{Concluding Remarks}

In concluding, we should return to Anthony Marx's insight: behind the seemingly liberal, voluntary, inclusive, "good" civic nationalisms of Western Europe, there is a dark history of ethnic exclusion based on religion. The ethnic exclusion of non-Muslims in Turkey did not end in Turkey in 1923 any more than the ethnic exclusion of non-Catholics ended with the St. Bartholemy's Day Massacre of French Protestants. Non-Muslims in Turkey continue to be frequently imagined outside "the nation" in ways that both the Muslim migrants to Turkey and domestic Muslim minorities like the Kurds and the Laz were not. This was done not only by society, as we can see in events from the Thrace Events (Trakya Olaylar) against the Jews to the assassination of the Armenian Turkish journalist Hrant Dink, but often by the state as well. This exclusion by the state was periodic, and the state went through periods of a tepid inclusionary discourse, punctuated by fierce moments of exclusion, like the Wealth Tax (Varlık Vergisi) and the 
Istanbul Pogrom of 1955. Since then, this question of inclusion or exclusion of non-Muslims has become less central to the Turkish national imagination, as the non-Muslims of Turkey has dwindled both in population and power. Some scholars (Içduygu, Toktas, and Soner 2008; McCarthy 1983), however, have argued that this ultimate dwindling was the product of a successful strategy of Turkish nationalism. Their treatment in late Ottoman and Turkish Republican periods provides a useful comparison for the treatment of Muslim minorities, both immigrant and indigenous, and shows how in the early Turkish state there was civic inclusion for Muslims and an ethnic-like exclusion of non-Muslims from the imagining of the emergent nation and state.

Anthony Marx's argument for Western Europe can largely be extended to Turkey: whatever inclusionary civic nationalism Turkey has, it is undergirded by a religious exclusion. However, rather than being an argument to dispense with civic and ethnic, this analysis shows the utility of the categories of ethnic and civic nationalism. It is imperative, though, to treat these as Weberian ideal types, not actually existing categories into which every form of nationalism must fit. It would be futile to try to argue $X$ is ethnic and $Y$ is civic, but instead we must see track ethnic and civic nationalism not with states and nations has a wholes, but with specific periods and policies. Brubaker is wrong to argue that we should dispense with these civic and ethnic categories in favor of state-building and stateopposed nationalism because those new categories would give us little insight into the ways Turkish nation has been imagined by Turkish state and society over time. However, he is right in pointing out that the relationship between civic and ethnic nationalism and liberal values is more complex than simply "civic is good and ethnic is bad". But that is a moral, rather than analytical, aspect. For our purposes, the largely but not entirely civic nationalism of the Early Turkish Republic is a useful analytical tool to understand how modern Turkey can be about $1 / 5$ the descendants of recent immigrants without having a cultural memory of being a state made of up immigrants. The Muslim migrants simply became Turks.

\section{References}

Al, Serhun. 2015. "Elite Discourses, Nationalism and Moderation: A Dialectical Analysis of Turkish and Kurdish Nationalisms." Ethnopolitics 14(1):94-112.

Anderson, Benedict. 2006. Imagined Communities: Reflections on the Origin and Spread of Nationalism. London; New York: Verso.

Armstrong, John Alexander. 1982. Nations before Nationalism. Chapel Hill, NC: University of North Carolina Press. 
Barkey, Karen. 2005. "Islam and Toleration: Studying the Ottoman Imperial Model." International Journal of Politics, Culture, and Society 19(1-2):5-19.

Barkey, Karen. 2008. Empire of Difference: The Ottomans in Comparative Perspective. Cambridge, UK: Cambridge University Press.

Braude, B. 1982. "Foundation Myths of the Millet System." Christians and Jews in the Ottoman Empire: The Functioning of a Plural Society 1:69-88.

Breuilly, John. 1994. Nationalism and the State. 1st ed. Chicago: University Of Chicago Press.

Brink-Danan, Marcy. 2009. "'I vote, therefore I am:' Rituals of Democracy and the Turkish Chief Rabbi" PoLAR: Political and Legal Anthropology Review 32(1):5-27.

Brink-Danan, Marcy. 2010. "Names That Show Time: Turkish Jews as 'Strangers' and the Semiotics of Reclassification." American Anthropologist 112(3): 384-396.

Brink-Danan, Marcy. 2012. Jewish Life in Turkey: the Other Side of Tolerance. Bloomington, IN: Indiana University Press.

Brubaker, Rogers. 1992. Citizenship and Nationhood in France and Germany. Cambridge, MA.: Harvard University Press.

Brubaker, Rogers. 2002. "Ethnicity without Groups." Archives Europeennes de Sociologie 43(2):163-89.

Brubaker, Rogers. 2006. Ethnicity without Groups. Cambridge, MA: Harvard University Press.

Brubaker, Rogers and Frederick Cooper. 2000. "Beyond 'identity."' Theory and Society 29(1):1-47.

Clark, Bruce. 2009. Twice a Stranger: The Mass Expulsions That Forged Modern Greece and Turkey. Cambridge, MA: Harvard University Press.

Ekmekçioğlu, Lerna. 2016. Recovering Armenia: the Limits of Belonging in Post-Genocide Turkey. Stanford, CA: Stanford University Press.

Ergin, Murat. 2014. "The Racialization of Kurdish Identity in Turkey." Ethnic and Racial Studies 37(2):322-41.

Gellner, Ernest. 2008. Nations and Nationalism. $2^{\text {nd }}$ Edition. Ithaca, NY: Cornell University Press.

Gürpinar, Doğan. 2012. "From the Bare and Arid Hills to Anatolia, the Loveable and Beautiful: Kemalist Project of 'National Modernity' in Anatolian Countryside." Middle Eastern Studies 48(6):903-26.

Hechter, Michael. 2000. Containing Nationalism. Oxford; New York: Oxford University Press.

Hobsbawm, E. J. 2012. Nations and Nationalism Since 1780: Programme, Myth, Reality. Cambridge, UK: Cambridge University Press.

Hroch, Miroslav. 1996. "From National Movement to the Fully-Formed Nation: The NationBuilding Process in Europe." Pp. 78-97 in Mapping the Nation, edited by G. Balakrishnan. New York; London: Verso.

Içduygu, Ahmet, Sule Toktas, and B. Ali Soner. 2008. "The Politics of Population in a NationBuilding Process: Emigration of Non-Muslims from Turkey." Ethnic \& Racial Studies 31(2):358-89.

Kohn, Hans. 2005. The Idea of Nationalism: A Study in Its Origins and Background. New Brunswick, NJ: Transaction Publishers.

Leder, Arnold. 1976. Catalysts of Change: Marxist Versus Muslim in a Turkish Community. Austin, TX: Center for Middle Eastern Studies.

Magnarella, Paul J. 1979. The Peasant Venture: Tradition, Migration, and Change among Georgian Peasants in Turkey. Cambridge, MA: Schenkman Publishing.

Marx, Anthony W. 2003. Faith in Nation: Exclusionary Origins of Nationalism. Oxford; New York: Oxford University Press.

McCarthy, Justin. 1983. "Foundations of the Turkish Republic: Social and Economic Change." Middle Eastern Studies 19(2):139-51. 


\section{Incorporation of Migrants and Minorities into the Turkish State}

Meeker, Michæl. 2002. A Nation of Empire: The Ottoman Legacy of Turkish Modernity. Berkeley, CA: University of California Press.

Meyer, James H. 2014. Turks Across Empires: Marketing Muslim Identity in the RussianOttoman Borderlands, 1856-1914. New York; Oxford: Oxford University Press.

Saraçoğlu, Cenk. 2010. "The Changing Image of the Kurds in Turkish Cities: Middle-Class Perceptions of Kurdish Migrants in Izmir." Patterns of Prejudice 44(3):239-60.

Scott, James C. 1985. Weapons of the Weak: Everyday Forms of Peasant Resistance. New Haven, CT: Yale University Press.

Shields, Sarah D. 2011. Fezzes in the River: Identity Politics and European Diplomacy in the Middle East on the Eve of World War II. Oxford; New York: Oxford University Press.

Smith, Anthony D. 1971. Theories Of Nationalism. London: Gerald Duckworth \& Company Limited.

Smith, Anthony D. 1989. "The Origins of Nations." Ethnic and Racial Studies 12(3):340-67.

Smith, Anthony D. 1991. The Ethnic Origins of Nations. Oxford, UK: Wiley-Blackwell.

Sullivan, Winnifred Fallers. 2005. The Impossibility Of Religious Freedom. Princeton, NJ: Princeton University Press.

Üngör, Uğur Ümit. 2008. "Seeing like a Nation-State: Young Turk Social Engineering in Eastern Turkey, 1913-50." Journal of Genocide Research 10(1):15-39.

Üngör, Uğur Ümit. 2011. The Making of Modern Turkey: Nation and State in Eastern Anatolia, 1913-1950. Oxford; New York: Oxford University Press.

Weber, E. J. 1976. Peasants Into Frenchmen: The Modernization of Rural France, 1870-1914. Stanford, CA: Stanford University Press.

Yeğen, Mesut. 1999. "The Kurdish Question in Turkish State Discourse." Journal of Contemporary History 34(4):555-68.

Yeğen, Mesut. 2009. "'Prospective-Turks' or 'Pseudo-Citizens': Kurds in Turkey." The Middle East Journal 63(4):597-615.

Zürcher, Erik-Jan. 2003. "The Young Turks: Children of the Borderlands?" International Journal of Turkish Studies 9(1/2):275-85.

Zürcher, Erik Jan. 2005. "How Europeans Adopted Anatolia and Created Turkey." European Review 13(03):379-94. 